\title{
La Isla Etaria. Tercera edad y medios de comunicación
}

Virginia Guarinos (Coord.)

ReaDuck, 2020

ISBN: 9788418406317

208 páginas

Sara Granero Ramos

sargraram@gmail.com

Universidad de Sevilla

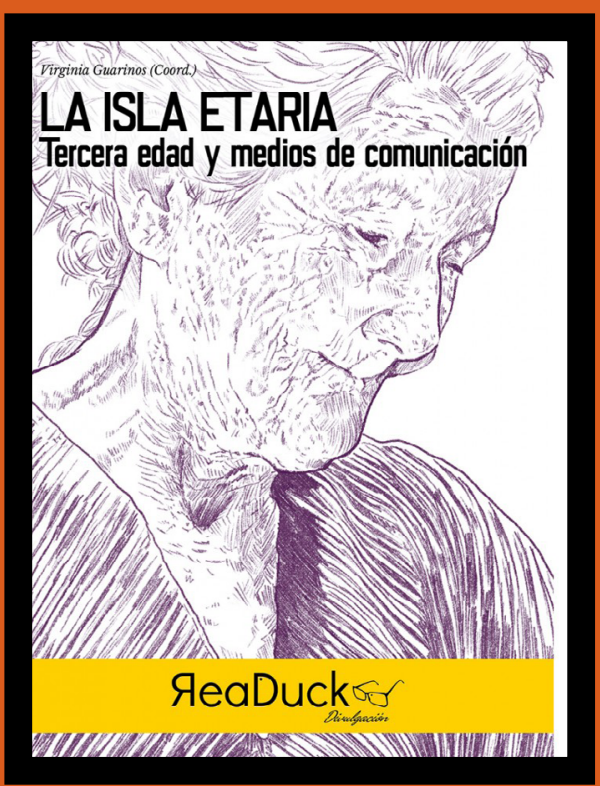

La Isla Etaria, el cuarto volumen de la colección divulgativa de la editorial Readuck, repasa el tratamiento de la tercera edad en los productos audiovisuales actuales. El libro analiza el trato desfavorable que a menudo sufren los mayores de 65 años en su representación, ya sea por su tratamiento desde el paternalismo o directamente por su invisibilización. Para reflejar estos prejuicios, el grupo de investigación AdMira (Análisis de Medios, Imágenes y Relatos Audiovisuales en su Historia para el Cambio Social, SEJ496) de la Universidad de Sevilla se embarca en un análisis que engloba diferentes ámbitos, como son el cine, la publicidad o internet, y su relación con este colectivo tan olvidado.

En los diez capítulos que conforman el manual, los autores abordan distintos formatos y medios de comunicación, como son la radio, la televisión o el cine, tanto series o películas como programas televisivos no ficcionales. También se exploran las posibilidades que ofrece internet o el mundo de los videojuegos, sectores que a priori parecen incompatibles con la tercera edad. Además, el proyecto adquiere un carácter transmedia al incluir el programa radiofónico homónimo de RadiUS, que complementa esta investigación fomentando la participación directa de personas de la tercera edad en ellos.

Al frente de la expedición rumbo a La Isla Etaria está Virginia Guarinos, directora de AdMira y Profesora Titular del Departamento de Comunicación Audiovisual y Publicidad de la Universidad de Sevilla. En su capítulo preliminar, Guarinos explica el interés de AdMira, que considera la investigación como una herramienta hacia el cambio social, por los estudios etarios. El "miedo al envejecimiento" está intrínseco en la cultura contemporánea, como apunta la autora, y se manifiesta relegando a la tercera edad a esa figura necesitada, que se encuentra al final de su existencia, en contraposición a la juventud saludable y llena de vida. En este libro, los mayores de 65 son los protagonistas del relato.

En el prólogo del manual, Francisco A. Zurian define el envejecimiento como constructo social, dependiente del contexto más que de unas características objetivas. 
Esto convierte a los estudios etarios en un área interdisciplinar, que se cruza con otro tipo de estudios, como los de género o los culturales. La edad, indica Zurian, es una realidad transversal, puesto que conlleva una serie de implicaciones que se entrelazan con otras derivadas de la clase, la raza, el género y la diversidad sexual.

La radio es el medio de comunicación tradicionalmente más asociado a la tercera edad, tanto por su longevidad, como por la fidelidad de los oyentes de este rango de edad. Virginia Guarinos dedica el primer capítulo de La Isla Etaria a este medio, analizando su relación con el sector envejeciente como consumidor y productor de discursos radiofónicos. Guarinos rastrea las cuatro emisoras generalistas más escuchadas en España, Cadena Ser, COPE, Onda Cero y RNE, en busca de aquellos programas dedicados a la tercera edad, así como producidos o locutados por mayores.

El ámbito cinematográfico es el protagonista de tres de las investigaciones recogidas en este volumen. Valeriano Durán Manso, en el capítulo segundo, centra el foco en las masculinidades envejecientes, concretamente la representada en La Juventud (Paolo Sorrentino, 2015). El autor señala la construcción de personajes como una de las señas de identidad de este cineasta. Los personajes principales de Sorrentino reflexionan sobre su propia existencia a través de la observación. En el caso de Fred Ballinger y Mick Boyle, intercambian sus pensamientos sobre la vida laboral, la paternidad y la salud. De esta forma, Sorrentino coloca en un lugar protagónico al envejeciente, acostumbrado a estar en un segundo plano.

En el décimo capítulo del libro, María Isabel Menéndez Menéndez escoge $O$ Que Arde (Oliver Laxe, 2019) para abordar la construcción de personajes femeninos que consiguen romper con los prejuicios etarios y patriarcales. La fortaleza de Benedicta se contrapone a la aparente fragilidad que se deduce de su aspecto físico. El éxito comercial de la película de Oliver Laxe demuestra que es posible ceder el protagonismo a una mujer mayor para contar historias desde una perspectiva alejada del edadismo.

Por otro lado, la representación en la gran pantalla de la sexualidad en la tercera edad es el objeto de estudio de Irene Liberia Vayá y Sergio Cobo-Durán en el capítulo número ocho de La Isla Etaria. Debido a su condición de tabú, esta temática permanece especialmente invisibilizada en los productos audiovisuales. Los autores, tras la revisión de la literatura especializada y el visionado de las películas que abordan la vida sexual en la vejez a partir del 2000, han analizado diez cintas en busca de los prejuicios y progresos de su representación en el cine del nuevo milenio.

En los últimos años, la pequeña pantalla se ha convertido en un escaparate para todo tipo de historias y temáticas. En el tercer capítulo, María Toscano Alonso escoge el ejemplo de Grace and Frankie (2015-presente), protagonizada por dos mujeres muy diferentes, ambas rondando los 70 años. Además del acercamiento a materias como la amistad o la sexualidad femenina en este rango de edad, esta serie trata también la homosexualidad, muy invisibilizada en los personajes mayores. Esta ficción recoge el testigo de Las Chicas de Oro, adaptando la temática a un tono más actual y arriesgado.

En cambio, en el siguiente capítulo, Laura Pacheco-Jiménez enfoca la presencia de la tercera edad en programas de no ficción, como por ejemplo La Resistencia. Este late night de Movistar+, cuyo público objetivo es puramente millennial, dedicó toda una semana a entrevistar a mujeres de más de 65 años. La denominada Yaya's Week, que resultó un triunfo de audiencia, contó con la presencia de la presentadora María Teresa 
Campos, la atleta Consuelo Alonso, la política Manuela Carmena y Chon Álvarez, abuela de uno de los colaboradores del programa.

Precisamente de la interacción de la tercera edad con productos aparentemente millennials trata el capítulo quinto, de Inmaculada Gordillo y Sergio Toledo. Las redes sociales se han convertido en el medio principal de comunicación, y cada vez hay más mayores conectados a ellas. Además, han surgido nuevas profesiones, como la del creador de contenidos. Gordillo y Toledo exploran plataformas como YouTube o Instagram en busca de perfiles de influencers mayores de 65 años.

Esta revolución digital que ha supuesto internet se refleja en el auge de las nuevas tecnologías. En el noveno capítulo del manual, Miguel Ángel Pérez Gómez revisa la imagen de las personas mayores en el sector publicitario, concretamente el orientado a los productos tecnológicos. Hasta el momento, este discurso estaba dominado por mensajes dirigidos a los jóvenes. Sin embargo, la población envejecida se ha convertido en el nuevo sujeto de este tipo de ventas, a consecuencia de la pandemia de la COVID-19.

También sobre publicidad trata el capítulo número seis de La Isla Etaria, de Inmaculada Sánchez-Labella Martín. Específicamente, la autora indaga sobre la representación del cuerpo femenino envejecido en las campañas de grandes marcas de belleza y cuidado personal. Además, incide en las connotaciones que se le vienen atribuyendo en los últimos años, en los que la tendencia a la naturalidad se ha instalado en el mundo publicitario.

Finalmente, Francisco Javier López Rodríguez e Irene Raya Bravo ahondan en el campo de los videojuegos en el séptimo capítulo. La mayoría de las investigaciones que relacionan la tercera edad con este sector se centran en delimitar los efectos que tiene jugar a videojuegos en la salud, física y mental, de este colectivo. Por el contrario, el capítulo del libro revisa el tratamiento de los gamers más longevos en la prensa online española especializada en videojuegos.

En conclusión, La Isla Etaria revisa la presencia de la tercera edad en diversos terrenos de la comunicación, cada uno con códigos de representación propios. La lectura de este manual muestra la responsabilidad de los medios en el tratamiento de aquellos colectivos más discriminados, derivada de su innegable impacto social. Con este volumen, además del programa de RadiUS también llamado La Isla Etaria, AdMira analiza la representación audiovisual de este colectivo con una clara voluntad social y crítica, base de su identidad investigadora. 